\title{
SOME PRECURSORS PRIOR TO RECENT GREAT EARTHQUAKES ALONG THE NANKAI TROUGH
}

\author{
Hiroshi SATo \\ Geographical Survey Institute, Tokyo, Japan \\ (Received April 20, 1977; Revised September 14, 1977)
}

To get suggestions for the researches of earthquake prediction in Tokai district, short-term precursors prior to the recent great earthquakes along the Nankai trough are investigated here.

The Tonankai earthquake. The anomalous tilt of the ground had been observed several hours before the occurrence of that earthquake by a leveling party surveying in Tokai district. The party said also that they recognized with a level unusual quakes of the ground just before the earthquake. It is interesting that the similar phenomena were reported by two survey parties in China.

The Nankai earthquake. From the analysis of hourly value of tidal records, precursory land uplift prior to the earthquake was recognized in the southwest coast of Shikoku. Although the reliability of that uplift was not so high, another precursory phenomena, abnormal changes in the ground water, had occurred in several wells in the area. It is, therefore, probable that there occurred significant changes in the crustal stress and strains prior to the earthquake.

It is noteworthy that those precursors were observed in the areas near the boundary of the focal regions of the earthquakes.

\section{Introduction}

The Tokai district is now drawing much attention of Japanese seismologists as the most likely candidate for a great earthquake in the near future, because there has occurred no major earthquake since 1854 when the Ansei Tokai earthquake struck the district. It is well known that a series of great earthquakes has occurred with a considerable temporal regularity along the Nankai trough, the mechanism of which is explained by a model that incorporates interactions between the Philippine Sea plate and continental lithosphere. Considering the temporal regularity, the Coordinating Committee for Earthquake Prediction in Japan assigned the district as the 'area of intensified observation' in 1974. Since then many kinds of observations have been intensified there by governmental organizations related to earthquake prediction researches.

In this paper are presented some precursors to recent great earthquakes along the Nankai trough, as they may give some suggestions for the researches for the prediction of the future Tokai earthquake. 


\section{Precursory Land Tilt Prior to the Tonankai Earthquake of 1944}

The earthquake occurred off of the east coast of Kii Peninsula in 1944 and caused severe damages to the Tokai district. When the earthquake occurred, a leveling party of the Military Land Survey had been surveying in the area near Kakegawa city and abnormal land tilt just before the earthquake was observed by chance. The survey was made at the request of the late Imamura who had anticipated the occurrence of a great earthquake in the region off of Tokai. He demanded that the Military Land Survey resurvey the leveling line near the Kakegawa and establish a new line from Kakegawa to Omaezaki. The Tonankai earthquake occurred when the survey had been under way, and important data of land movement were obtained through the leveling.

Figure 1 shows the vertical land movement associated with the earthquake. Clear coseismic uplift of more than $10 \mathrm{~cm}$ is remarkable in the area near Kakegawa, but no significant land movement occurred at Omaezaki where large uplift of about $1 \mathrm{~m}$ was reported at the Ansei Tokai earthquake of 1854 . This means that no fault-
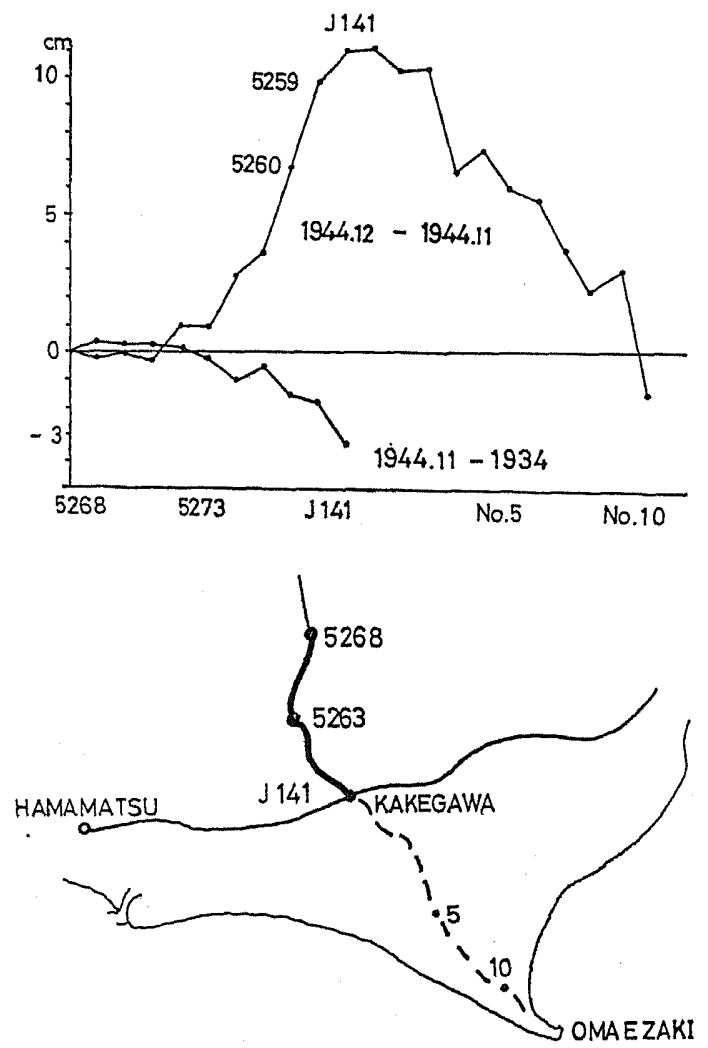

Fig. 1. Vertical movement of the leveling line surveyed just before and after the Tonankai earthquake of 1944. Dash line shows the line established before the earthquake by the request of the late Imamura. 


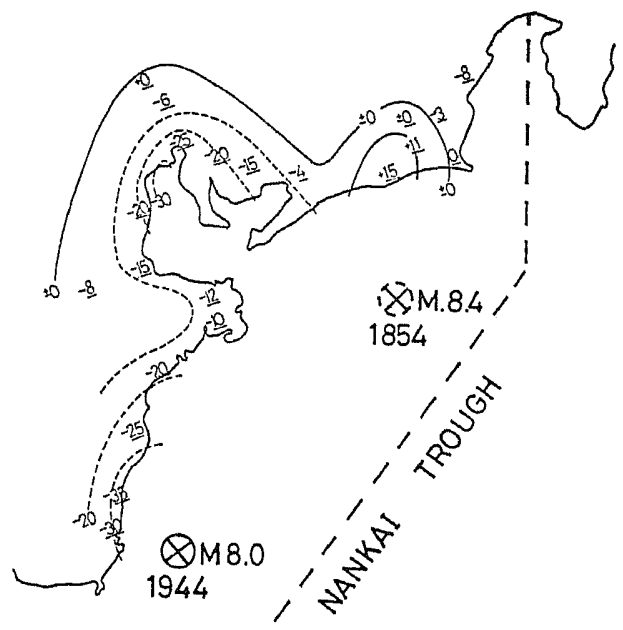

Fig. 2. Vertical movement of the crust associated with the Tonankai earthquake of 1944 (after INOUCHI and SATO, 1975).

Table 1. Survey results of the section 5260-5259.

\begin{tabular}{crcc}
\hline Section & \multicolumn{1}{c}{ Time } & Result & Diff. \\
\hline $5259 \rightarrow 5260$ & $10 \mathrm{~h} 30 \mathrm{~m} \rightarrow 12 \mathrm{~h} 30 \mathrm{~m}$ & $-7.7554 \mathrm{~m}$ & \\
& $\begin{array}{r}\text { th } \mathrm{thec} . \\
5260 \rightarrow 5259\end{array}$ & $+7.7636 \mathrm{~m} \quad 40 \mathrm{~m} \rightarrow 12 \mathrm{~h} 13 \mathrm{~m}$ & $+8.2 \mathrm{~mm}$
\end{tabular}

Origin time $13 \mathrm{~h} 35 \mathrm{~m}, 7$ th Dec. 1944.

ing took place offshore of Omaezaki during the earthquake of 1944, although the source area is considered to extend to the area near the Kakegawa (INOUCHI and SATO, 1975).

The origin time of the earthquake is $13 \mathrm{~h} 35 \mathrm{~m}, 7$ th December of 1944. In the morning of the day, the leveling party had surveyed the section from No. 5260 to No. 5259. The survey of the reverse direction had been made in the morning of the day before. If there were any precursory movement, it might be revealed as a discrepancy between the levelings made the day of the earthquake and the day before. In Table 1, time, the results, and the difference are presented. As seen in the table the discrepancy between the fore- and back-levelings in that section are abnormally large as compared with the usual accuracy of the first order leveling in Japan. No such phenomena are recognized in the data of the sections surveyed earlier than 5 th December. From these facts, it is concluded that a significant land tilt had happened within $24 \mathrm{hr}$ before the earthquake. To confirm this speculation, the survey data have been examined minutely. At the first order leveling, one must set some check points in a section in order to check the difference of fore- and back-surveys, so we are able to check the reliability of the data by the check points.

Figure 3 shows the differences of the observed heights between the check points 

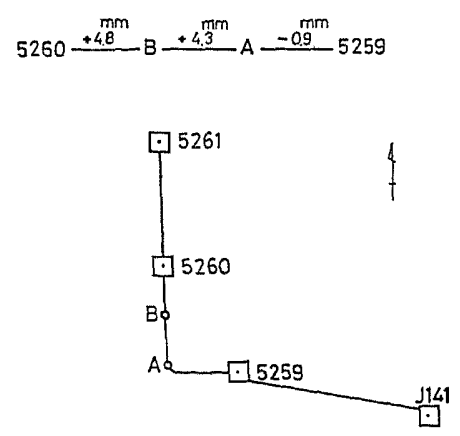

Fig. 3. Location of the check points in the section from No. 5259 to 5260 where the survey made just before the earthquake, and differences between the check points in the results of fore- and back-levelings.

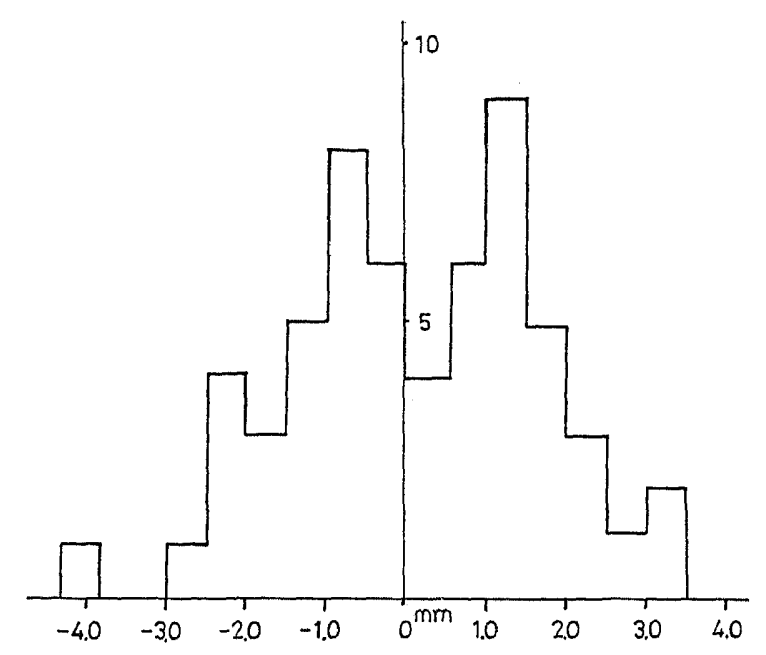

Fig. 4. Frequency distribution of errors in the subsections, discrepancies between fore- and back-surveys, surveyed by the same observer. The figure does not contain those in Fig. 3.

in the concerned section, in which the subsections of N-S direction show significantly large differences, but that of the E-W direction does not change. The changes are in good accord with the pattern of the coseismic movement of the crust shown in Fig. 2. To show the accuracy of the survey, frequency distribution of errors by the same observer is presented in Fig. 4. Only one subsection among 59 subsections has the error of $4 \mathrm{~mm}$, so it can be said that the probability that the precursory change was a spurious one resulting from the errors is not zero but very small. Before the earthquake, the same leveling party experienced an unusual phenomenon of the ground. They reported that the bubble of their instrument manifested unstable movement of slow quake several minutes before the earthquake. They suspended the surveying, as the bubble could not be adjusted. It is interesting that such unusual behaviors of a level bubble before earthquake were reported by Chinese survey parties with regard to two large earthquakes in China, namely Hsingtai earthquake of 1966 and Tonghai earthquake of 1970 (National Planning Committee of China, 1976). 


\section{Precursory Changes Prior to the Nankai Earthquake of 1946}

Two years after the Tonankai earthquake, another large earthquake, the Nankai earthquake, occurred offshore of Kii and Shikoku. In the case of the Nankai earthquake, we have no survey data taken just before the event, but the tidal data at Tosashimizu in Shikoku give us some suggestions about the precursory changes.

Figure 5 shows hourly differences of the sea level at Tosashimizu and Hosojima in Kyushu before the earthquake. In spite of a remarkable daily variation due to the dynamical effect of tidal current on the differences, a significant change of the differences can be recognized in the data from 19th December to 21st, when the earthquake occurred. The coast of Tosashimizu uplifted about $50 \mathrm{~cm}$ at the time of the earthquake, but no such movement was observed at Hosojima, so it is reasonable to assume that the change begun one day and a half before the event shows a preseismic uplift of the coast of Tosashimizu as a very short term precursor of the earthquake.

Although the reliability of the precursory movement from the tidal data is not so high, other precursory changes were reported by the Hydrographic Department. The department conducted a systematic investigation of the changes in the ground water due to the earthquake along the coast of Kii and Shikoku, and reported that abnormal muddyings or falls of the ground water had been observed before the earthquake in many wells in the area (KomUKar, 1948). For example, a well that

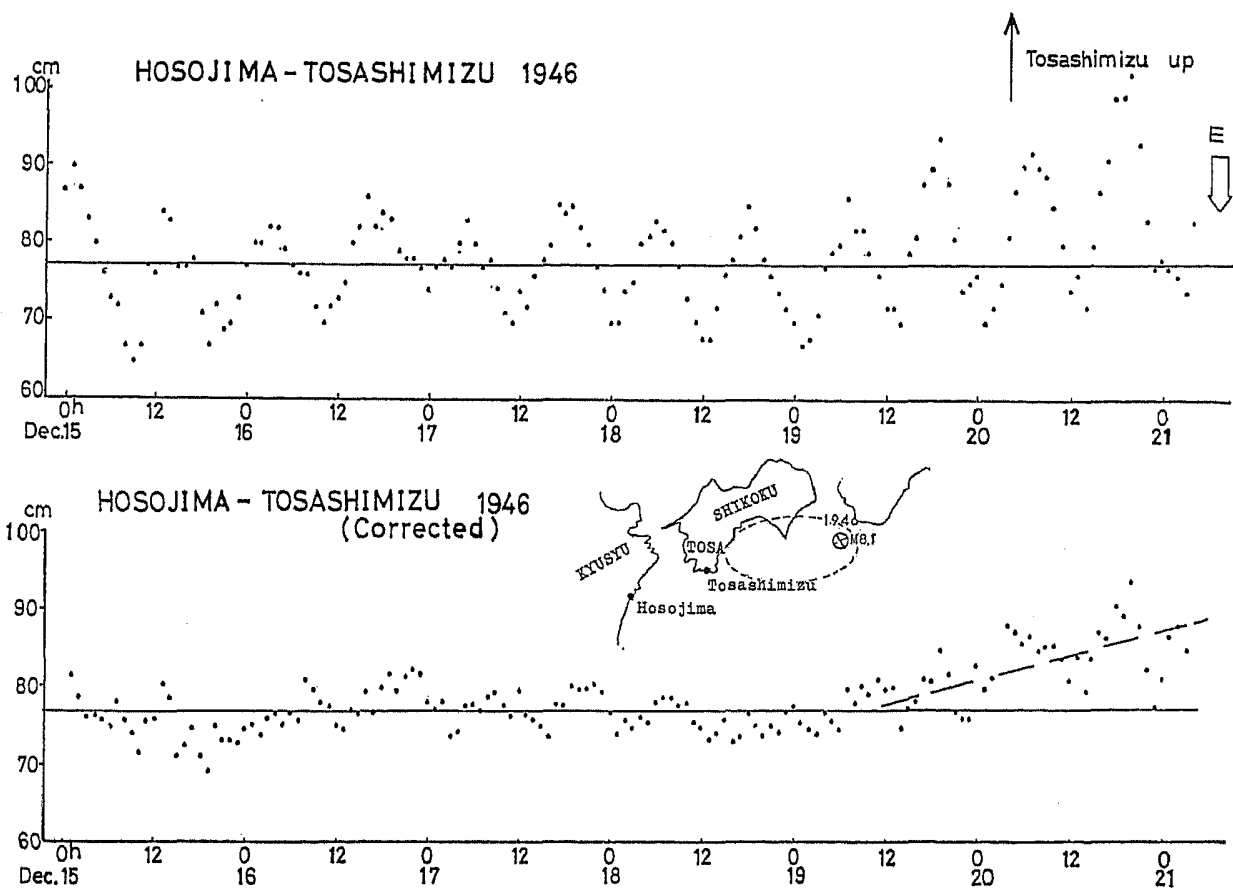

Fig. 5. Changes in the differences of hourly values of the sea level at Tosashimizu (Shikoku) and Hosojima (Kyushu) before the Nankai earthquake of 1946. The lower is the ones with a correction of the effect of tidal current. 


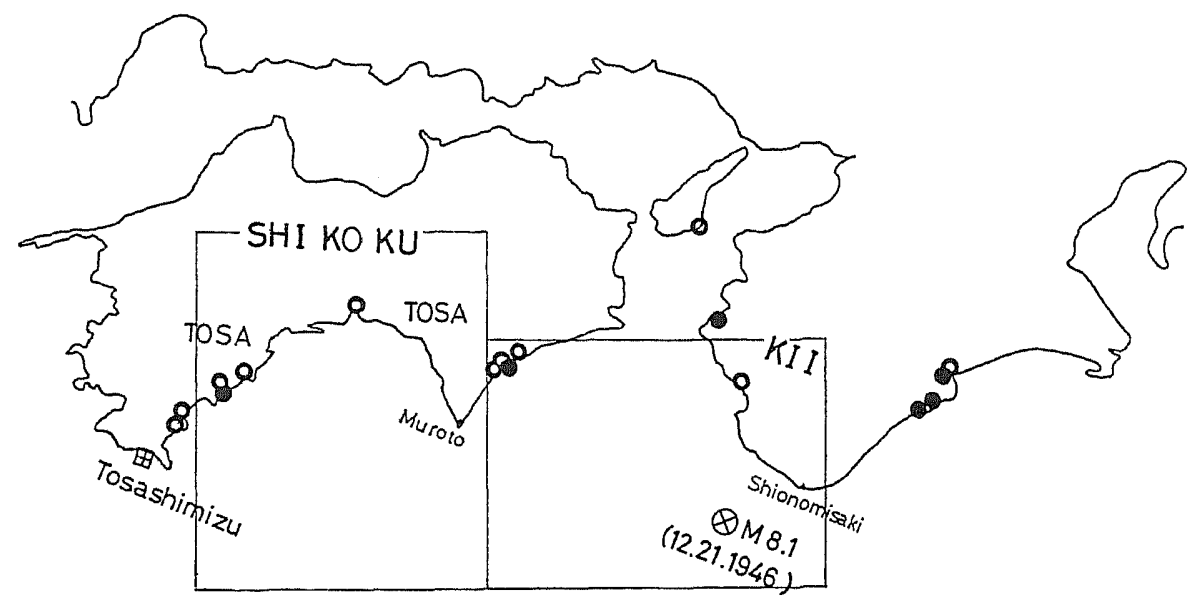

Fig. 6. Distribution of wells in which abnormal changes were observed in the ground water before the Nankai earthquake of 1946 . The open circles represent the wells that became dry or where lowering of the water was observed, and the filled ones show those becoming muddy. Those changes begun 5-7 days before the event in the coast of Tosa and one or two days before along the coast of $\mathrm{Kii}$ and east Shikoku. The rectangles show the source model of the earthquake by ANDO (1975), the left of which is estimated as a part of aseismic movement.

had not dried out in any dry seasons ran dry several days before the event. The distribution of the wells where such precursory change was observed is shown in Fig. 6. The report of the Hydrographic Department mentioned that some peole in Shikoku had been preparing for evacuation before the earthquake, as they anticipated the occurrence of the earthquake by the sudden fall of the ground water level and their old experiences with it.

Taking into account the above-mentioned facts, it could be said that there occurred observable precursory changes of short term in the stress and strains along the coast of the source area of the earthquake of 1946.

\section{Concluding Remark}

Both earthquakes of 1944 and 1946 occurred in the time of confusion owing to the second world war, so we have not much data available for the present purpose. Nevertheless we are convinced from the data presented here that the prediction of the coming Tokai earthquake is promising, as the earthquake is expected to be preceded by certain short-term precursors. It is also noteworthy that the precursors presented here were observed in the areas near the boundary of the focal regions of the earthquakes. On the contrary, we have no data suggesting a long-term anomaly in the crustal movement. Figure 7 shows the vertical movement of the Kii Peninsula before the both earthquake deduced from the data of leveling and the tide observation at Kushimoto. From the figure, it is supposed that the southern part of the peninsula had subsided with a constant rate of 5-6 mm/year until the earthquake of 1944 . 

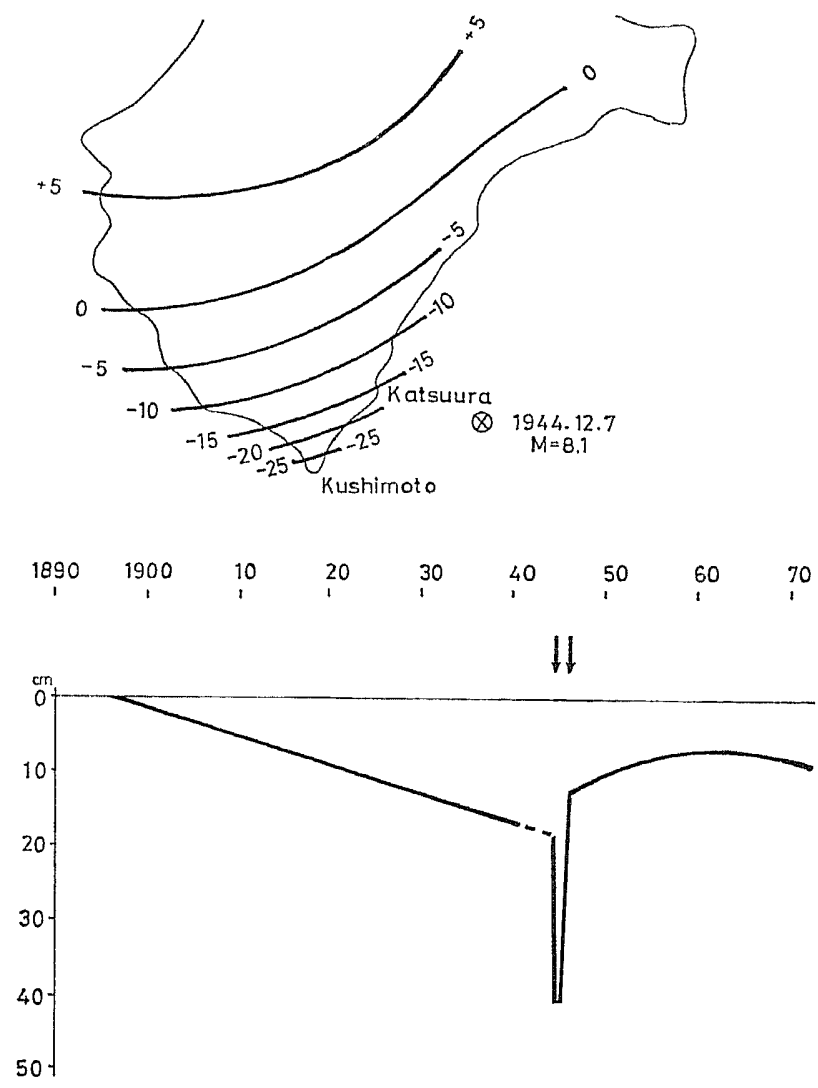

Fig. 7. Vertical movement of the Kii Peninsula in 50 years before the Tonankai earthquake of 1944 . The lower is the movement of Katsuura before and after the earthquake of 1944 and 1946.

The author wishes to express his sincere thanks to Dr. Takahiro Hagiwara, Honorary Professor of Tokyo University, for encouragement in carrying out the present work. He also wishes to thanks to Mr. Hiroshi Hori and Mrs. Setsuko Yamada, his colleagues, for their assistances in the work.

\section{REFERENCES}

ANDo, M., Source mechanisms and tectonic significance of historical earthquakes along the Nankai trongh, Japan, Tectonophysics, 27, 119-140, 1975.

INOUCHI, N. and H. SATO, Vertical crustal deformation accompanied with the Tonankai earthquake of 1944, Bull. Geogr. Surv. Inst., 21, 10-18, 1975.

Komukat, R., Changes in the ground water associated with the Nankai earthquake of 1946, Report on the Nankai Earthquake, Hydrogr. Bull., Spec. No., 1948 (in Japanese).

National Planning Committee of China, Questions and Answers for Earthquake, translated into Japanese by K. Hoshino, Tokuma-Shoten, Tokyo, 1976. 